\title{
Aqueous-phase preparation of model HDS \\ catalysts on planar alumina substrates: support effect on Mo adsorption and sulfidation.
}

Cédric Bara, ${ }^{[\mathrm{a}, \mathrm{b}, \mathrm{c}]}$ Lucie Plais, ${ }^{[\mathrm{a}, \mathrm{b}]}$ Kim Larmier, ${ }^{[\mathrm{a}, \mathrm{b}]}$ Elodie Devers, ${ }^{[\mathrm{c}]}$ Mathieu Digne,${ }^{[\mathrm{c}]}$ Anne-Félicie Lamic-Humblot, ${ }^{[\mathrm{a}, \mathrm{b}]}$ Gerhard D. Pirngruber, ${ }^{[\mathrm{c}]}$ and Xavier Carrier*[a,b]

\section{Supporting Information}

AFM images of the oxide phase
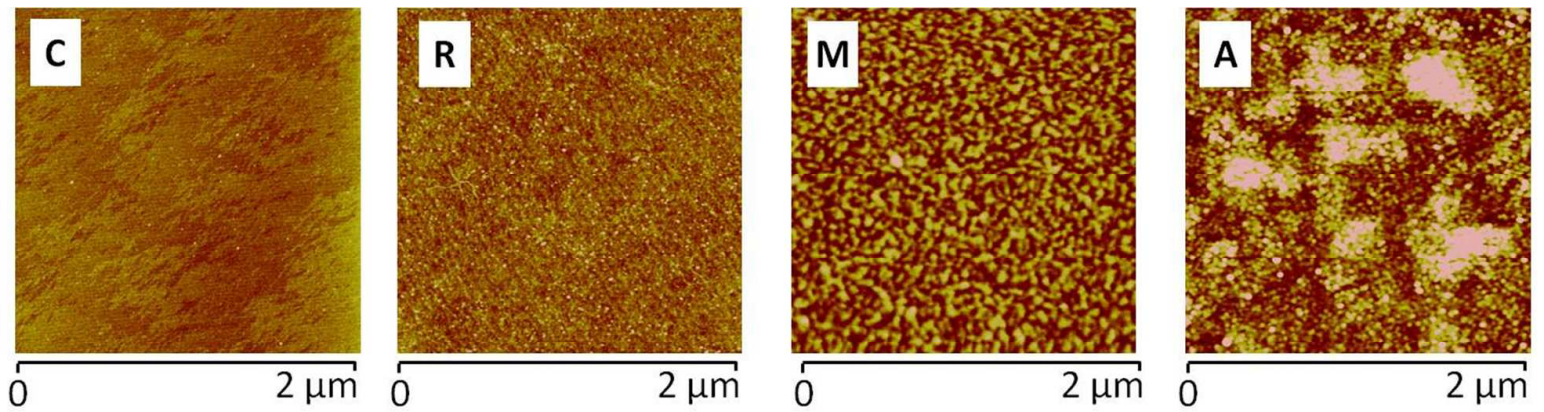

Figure S1. Representative AFM images ( $2 \times 2 \mu \mathrm{m}^{2}$, Peak Force Tapping mode in air, z-scale $\left.4 \mathrm{~nm}\right)$ of planar $\mathrm{Mo} / \alpha-\mathrm{Al}_{2} \mathrm{O}_{3}$ model catalysts obtained for a selective adsorption of a $4.10^{-2} \mathrm{M}$ Mo solution and calcined at $450{ }^{\circ} \mathrm{C}$ for $2 \mathrm{~h}$ with various alumina orientations: $\mathrm{C}(0001), \mathrm{R}(1 \overline{1} 02), \mathrm{M}(10 \overline{1} 0)$ and A (11 $\overline{2} 0)$ planes. 


\section{DFT Calculations}

\section{1) Surface Models}

1.1 The M (10̄0) surface was modeled using a tri-periodic cell with a size of $4.76 \times 12.99 \times 32.97 \AA^{3}$, leading to a $15 \AA$-thick alumina slab (normal to the $\mathrm{O} z$ axis) covered by $18 \AA$-wide vacuum slab. The alumina slab contains 12 atomic layers. All atoms are allowed to relax during geometry optimizations, so that the simulation cell contains two surfaces (one on the top and one on the bottom of the slab). The Brillouin zone integration is performed on a $5 \times 2 \times 1 k$ points grid mesh. The model of the dehydrated surface is shown on Figure S1-(a). The elementary cell (which is also the simulation cell) contains 4 non-equivalent tetra-coordinated surface aluminum atoms in tetrahedral geometry, noted $\mathrm{Al}_{4 \mathrm{c}}(\mathrm{n})$ with $\mathrm{n}$ from 1 to 4 on Figure $\mathrm{S} 2$. Several surface oxygen atoms bi-coordinated (noted $\mu_{2}-\mathrm{O}(\mathrm{n})$ with $\mathrm{n}$ from 1 to 3 ) and tri-coordinated (noted $\mu_{3}-\mathrm{O}(\mathrm{n})$ with $\mathrm{n}$ from 1 to 2 ) can be found on this model.

1. 2 The A (11 $\overline{2} 0)$ surface was modeled using a tri-periodic cell with a size of $8.24 \times 12.99 \times 26.0 \AA^{3}$, leading to a $11 \AA$-thick alumina slab (normal to the $\mathrm{O} z$ axis) covered by a $15 \AA$ A-wide vacuum slab. The alumina slab contains 10 atomic layers. All atoms are allowed to relax during geometry optimizations, so that the simulation cell contains two surfaces (one on the top and one on the bottom of the slab). The Brillouin zone integration is performed on a $2 \times 2 \times 1 k$ points grid mesh. The model of the dehydrated surface is shown on Figure S2-(b).

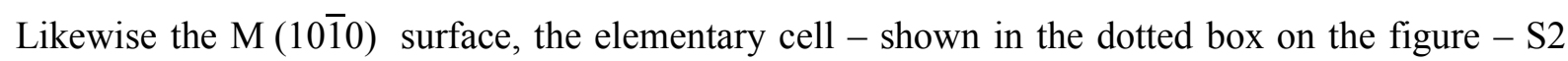
contains 4 non-equivalent penta-coordinated surface aluminum atoms, noted $\mathrm{Al}_{5 \mathrm{c}}(\mathrm{n})$ with $\mathrm{n}$ from 1 to 4 , non-equivalent surface oxygen atoms can be found (noted $\mu_{2}-\mathrm{O}$ and $\mu_{3}-\mathrm{O}(\mathrm{n})$ with $\mathrm{n}$ from 1 to 2 ), the other oxygen atoms being in the sub-surface region. We used a quadrangular simulation box containing three times the elementary cell for the calculations (plain box on Figure S2-(b)). 
(a)

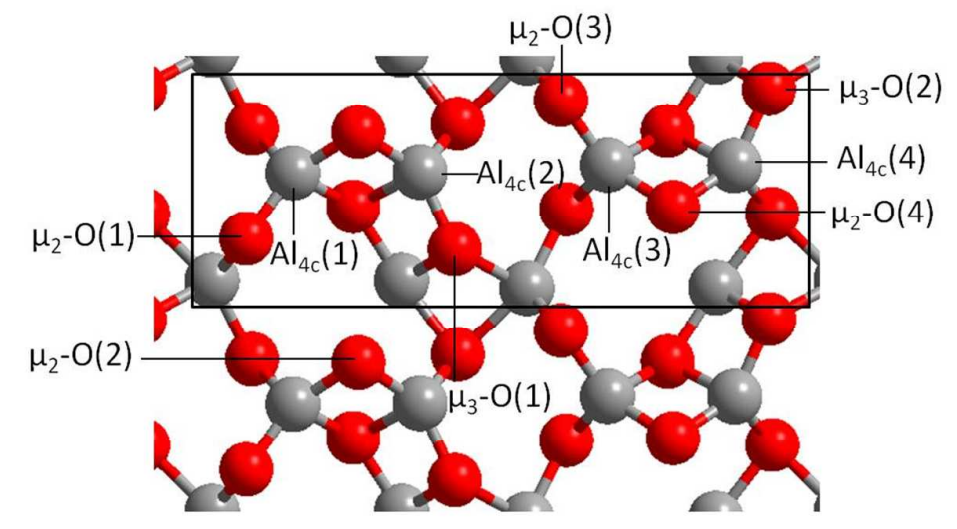

(b)

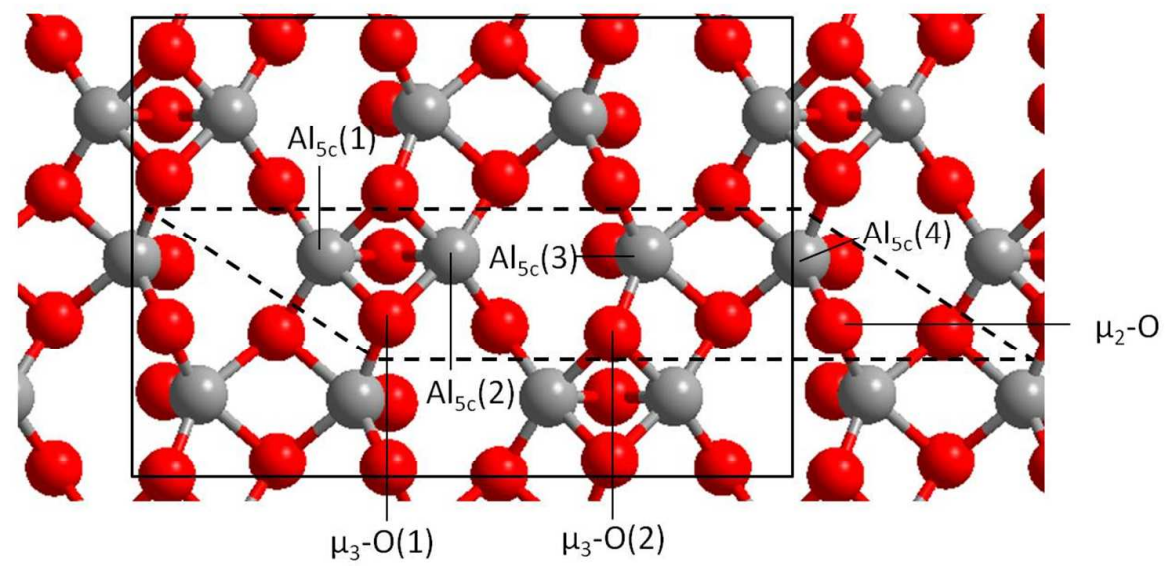

Figure S2. Optimized $\alpha$-alumina surface models (a) M (1010) surface; the box delimits the simulation box

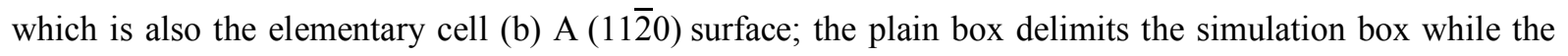
dotted box shows the surface elementary cell. Atoms that are not labeled in the elementary cells are subsurface atoms. Grey: aluminum atom, red: oxygen atom.

\section{2) Thermodynamics}

The surface energies of the hydrated surfaces have been evaluated following the procedure described in reference. ${ }^{1}$ For the two terminations studied X $(\mathrm{M}(10 \overline{1} 0)$ or $\mathrm{A}(11 \overline{2} 0))$, we considered the adsorption of $n_{\text {ads }}$ water molecules:

$$
\text { Surface }_{X}+n_{a d s} \mathrm{H}_{2} \mathrm{O}_{(\mathrm{g})}=\left[\text { Surface }_{X}, n_{a d s} \mathrm{H}_{2} \mathrm{O}\right]
$$

The change of the Gibbs free energy associated to this reaction at a given temperature $\mathrm{T}$ and water partial pressure $\mathrm{P}_{\mathrm{H} 2 \mathrm{O}}$ is

$$
\Delta_{\mathrm{r}} \mathrm{G}_{X}\left(\mathrm{~T}, \mathrm{P}_{\mathrm{H} 2 \mathrm{O}}\right)=\mathrm{G}\left(\left[\text { Surface }_{X}, n_{\text {ads }} \mathrm{H}_{2} \mathrm{O}\right]\right)\left(\mathrm{T}, \mathrm{P}_{\mathrm{H} 2 \mathrm{O}}\right)-\mathrm{G}\left(\text { Surface }_{X}\right)\left(\mathrm{T}, \mathrm{P}_{\mathrm{H} 2 \mathrm{O}}\right)-n_{\text {ads }} \mu_{\mathrm{H} 2 \mathrm{O}}\left(\mathrm{T}, \mathrm{P}_{\mathrm{H} 2 \mathrm{O}}\right)
$$

where $\mathrm{G}($ Surface $)\left(\mathrm{T}, \mathrm{P}_{\mathrm{H} 2 \mathrm{O}}\right)$ is the molar free energy of the considered surface species, and $\mu_{\mathrm{H} 2 \mathrm{O}}\left(\mathrm{T}, \mathrm{P}_{\mathrm{H} 2 \mathrm{O}}\right)$ the chemical potential of water in the gas-phase. For the surface species, we neglected 
the $p V$ terms contributions to the molar enthalpy and we assumed that the temperature dependence of the internal energies is due to the desorbed water molecules only $\left(\mathrm{U}_{\mathrm{H} 2 \mathrm{O}}(\mathrm{T})\right)$. Moreover, the entropy difference of the surface with or without adsorbed water is considered to be zero, so that entropic terms are hold by water only $\left(\mathrm{TS}_{\mathrm{H} 2 \mathrm{O}}(\mathrm{T})\right)$, and equation $(\mathbf{N 2})$ becomes

$$
\begin{aligned}
& \Delta_{\mathrm{r}} \mathrm{G}_{X}\left(\mathrm{~T}, \mathrm{P}_{\mathrm{H} 2 \mathrm{O}}\right)=\mathrm{E}\left(\left[\text { Surface }_{X}, n_{\text {ads }} \mathrm{H}_{2} \mathrm{O}\right]\right)(0 \mathrm{~K})-\mathrm{E}\left(\text { Surface }_{X}\right)(0 \mathrm{~K})-n_{a d s} \mathrm{x}\left[\mathrm{E}_{\mathrm{H} 2 \mathrm{O}}(0 \mathrm{~K})+\right. \\
& \left.\mathrm{U}_{\text {trans, } \mathrm{H} 2 \mathrm{O}}\left(\mathrm{T}, \mathrm{P}_{\mathrm{H} 2 \mathrm{O}}\right)+\mathrm{U}_{\mathrm{rot}, \mathrm{H} 2 \mathrm{O}}(\mathrm{T})+\left(\mathrm{U}_{\mathrm{vib}, \mathrm{H} 2 \mathrm{O}}(\mathrm{T})-\mathrm{ZPVE}_{\mathrm{H} 2 \mathrm{O}}\right)+\mathrm{RT}-\mathrm{TS}_{\mathrm{H} 2 \mathrm{O}}\left(\mathrm{T}, \mathrm{P}_{\mathrm{H} 2 \mathrm{O}}\right)\right]
\end{aligned}
$$

where $\mathrm{E}$ is the nuclear and electronic energy at $0 \mathrm{~K}$ of the considered species, $\mathrm{U}_{\text {trans, } \mathrm{H} 2 \mathrm{O}, \mathrm{U}_{\text {rot, } \mathrm{H} 2 \mathrm{O}} \text { and }}$ $\mathrm{U}_{\mathrm{vib}, \mathrm{H} 2 \mathrm{O}}$ are the translational, rotational and vibrational contributions to the internal energy of water in the gas-phase. For the latter, the zero point vibrational energy had to be withdrawn to ensure the consistency of the calculation, as the vibrational contributions were not evaluated for the surface species. The term $\mathrm{RT}$ is the $p V$ contribution to the enthalpy provided that water is considered as an ideal gas.

We define $\Delta_{\mathrm{r}} \mathrm{g}_{X}$ such as

$$
\Delta_{\mathrm{r}} \mathrm{G}\left(\mathrm{T}, \mathrm{P}_{\mathrm{H} 2 \mathrm{O}}\right)=n_{a d s} \Delta_{\mathrm{r}} \mathrm{g}_{X}
$$

and finally the surface energy $\Gamma_{X}$ of the hydrated surface is given by

$$
\Gamma_{X}=\Gamma_{X}^{0}+\theta_{X} \frac{\Delta_{\mathrm{r}} g_{X}}{2}
$$

where $\theta_{X}$ is the hydroxyl surface coverage and is equal to $2 n_{a d s} / A_{X}\left(A_{X}\right.$ is the area of the $X$ surface model), and $\Gamma^{0}$ is the surface energy of the fully dehydrated surface, referenced to the bulk free energy.

The thermodynamic calculations of water in the gas-phase were performed using the Dmol software $^{2}$ (although its electronic and nuclear energy at $0 \mathrm{~K}$ was calculated by VASP).

\subsection{Hydrated M (1010) surface}

For the most stable optimized surface structure, the following distribution of hydroxyl groups is obtained (see Figure 3 of the article):

- $\quad \mu_{1}-\mathrm{OH}(1),(2)$ and (3): formed by adsorption of an $\mathrm{OH}^{-}$moiety on $\mathrm{Al}_{4 \mathrm{c}}(2), \mathrm{Al}_{4 \mathrm{c}}(3)$ and $\mathrm{Al}_{4 \mathrm{c}}(4)$;

- $\quad \mu_{2}-\mathrm{OH}(1)$ and (2): formed by coordination of an $\mathrm{OH}^{-}$moiety bridging $\mathrm{Al}_{4 \mathrm{c}}(1)$ and $\mathrm{Al}_{4 \mathrm{c}}(2)$ or $\mathrm{Al}_{4 \mathrm{c}}(3)$ and $\mathrm{Al}_{4 \mathrm{c}}(4)$ surface sites; 
- $\quad \mu_{2}-\mathrm{OH}(3)$ and (4): formed by adsorption of an $\mathrm{H}^{+}$moiety on $\mu_{2}-\mathrm{O}(1)$ or $\mu_{2}-\mathrm{O}(3)$ surface oxygen atoms;

- $\mu_{3}-\mathrm{OH}(2)$ : formed by the adsorption of an $\mathrm{H}^{+}$moiety on $\mu_{3}-\mathrm{O}(1)$ and $\mu_{3}-\mathrm{O}(2)$ surface oxygen atoms;

- $\quad \mu_{3}-\mathrm{OH}(1)$ and (3): made by adsorption of an $\mathrm{H}^{+}$moiety on the $\mu_{2}-\mathrm{O}(2)$ and $\mu_{2}-\mathrm{O}(4)$ surface oxygen atoms, which then form an additional bond to a subsurface aluminum atom upon hydration.

\section{2 Hydrated A (11 $\overline{2} 0)$ surface}

For the most stable optimized surface structure, the following distribution of hydroxyl groups is obtained (see Figure 4 of the article):

- $\quad \mu_{1}-\mathrm{OH}(1)$ and (2): formed by the adsorption of an $\mathrm{OH}^{-}$moiety on $\mathrm{Al}_{5 \mathrm{c}}(1)$ and $\mathrm{Al}_{5 \mathrm{c}}(2)$;

- $\quad \mu_{2}-\mathrm{OH}(1)$ : formed by the coordination of an $\mathrm{OH}^{-}$on both $\mathrm{Al}_{5 \mathrm{c}}(3)$ and $\mathrm{Al}_{5 \mathrm{c}}(4)$;

- $\quad \mu_{2}-\mathrm{OH}(2)$ : formed by adsorption of a proton on $\mu_{2}-\mathrm{O}$ surface atoms;

- $\quad \mu_{3}-\mathrm{OH}(1)$ and (2): formed by adsorption of a proton on $\mu_{3}-\mathrm{O}(1)$ and $\mu_{3}-\mathrm{O}(2)$ surface oxygen atoms;

\section{References}

(1) Digne, M.; Sautet, P.; Raybaud, P.; Euzen, P.; Toulhoat, H. J. Catal. 2002, 211 (1), 1-5.

(2) Delley, B. J. Chem. Phys. 1990, 92 (1), 508-517. 


\section{Decomposition of S2p peak}
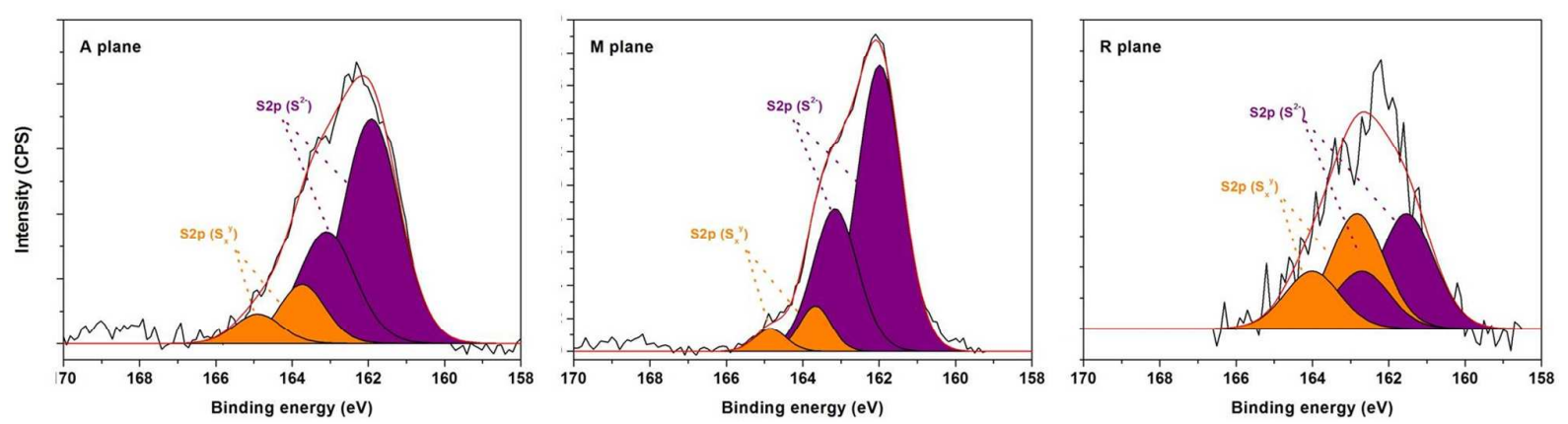

Figure S3. S2p peak decomposition for model catalysts obtained for a Mo concentration of $4.10^{-2} \mathrm{M}$, calcined at $450{ }^{\circ} \mathrm{C}$ for $2 \mathrm{~h}$ and sulfided at $450{ }^{\circ} \mathrm{C}$ for $2 \mathrm{~h}$ supported on $\mathrm{A}(11 \overline{2} 0), \mathrm{M}(10 \overline{1} 0)$ and $\mathrm{R}(1 \overline{1} 02) \alpha$ alumina single crystal substrate. 